University of Nebraska - Lincoln

DigitalCommons@University of Nebraska - Lincoln

Roman L. Hruska U.S. Meat Animal Research

U.S. Department of Agriculture: Agricultural Center

Research Service, Lincoln, Nebraska

1985

\title{
The Effects of Carcass Electrical Stimulation and Cooler Temperature on the Quality and Palatability of Bull and Steer Beef
}

John D. Crouse

U.S. Meat Animal Research Center

Steven C. Sideman

U.S. Meat Animal Research Center

H. Russell Cross

Texas A \& M University

Follow this and additional works at: https://digitalcommons.unl.edu/hruskareports

Part of the Animal Sciences Commons

Crouse, John D.; Sideman, Steven C.; and Cross, H. Russell, "The Effects of Carcass Electrical Stimulation and Cooler Temperature on the Quality and Palatability of Bull and Steer Beef" (1985). Roman L. Hruska U.S. Meat Animal Research Center. 37.

https://digitalcommons.unl.edu/hruskareports/37

This Article is brought to you for free and open access by the U.S. Department of Agriculture: Agricultural Research Service, Lincoln, Nebraska at DigitalCommons@University of Nebraska - Lincoln. It has been accepted for inclusion in Roman L. Hruska U.S. Meat Animal Research Center by an authorized administrator of DigitalCommons@University of Nebraska - Lincoln. 


\section{The Effects of Carcass Electrical Stimulation and Cooler Temperature on the Quality and Palatability of Bull and Steer Beef}

John D. Crouse, Steven C. Seideman, and H. Russell Cross'

\section{Introduction}

The advantages of producing bulls as opposed to steers in production efficiency, performance, and carcass leanness have been well documented. However, it also has been observed that bulls have darker colored lean and lower carcass quality grades than steers. In all studies summarized in a literature review, meat obtained from bulls was less tender when compared with meat from steers. Consequently, the superiority of bulls over steers in performance and carcass cutability have been largely countered by the inferior carcass quality of bulls. Production of beef by bulls, therefore, has not been widely undertaken in the United States.

Recent technological advances in meat processing may enhance bull beef quality. A review indicates that electrical stimulation of prerigor carcasses will improve tenderness and enhance lean color and marbling of beef. Improvement in tenderness by electrical stimulation was greatest when control samples had higher shear force requirements.

High temperature, early postmortem carcass conditioning may also improve palatability characteristics of meat from bulls.

Improvement in visual appeal and palatability of bull beef would certainly be in the best interest of the beef industry. The objective of this study was to examine postmortem treatments that could lead to improved meat quality of beef obtained from bulls. Methods studied were carcass electrical stimulation and high temperature conditioning.

\section{Procedures}

Animals. Carcasses were obtained from Hereford bulls ( 44 head) and Hereford steers (27 head) that were born in March or April, weaned at 8 months of age, and fed a corn silage diet until 15 months of age. Animals were then fed, until slaughter, an 84 percent total digestible nutrient corn-corn silage diet supplemented with soybean meal and minerals. Bulls were fed in one pen as a group, and steers were fed in another pen as a group.

Slaughter. Steers were slaughtered when the average 12th rib fat thickness for all steers was .5 in (17 mo of age), as evaluated by visual appraisal. Bulls were slaughtered when the average 12th rib fat thickness for all bulls was . 3 in (18 mo of age), as evaluated by visual appraisal. Bulls were selected with less fat thickness than steers because it was considered unreasonable to feed bulls to weights required to attain fat thicknesses equivalent to those of fed market weight steers. It was also considered that one of the competitive advantages of bulls for beef production was leanness.

Postmortem Treatments. Carcasses were split, each side weighed, and the right side electrically stimulated (ES) within $1 \mathrm{~h}$ postmortem. The ES consisted of 17 impulses at 550 volts (AC), 2 to 2.5 amps and $60 \mathrm{~Hz}$ for a 1.8-sec duration with a 1.8-sec pause between impulses. The left sides were used as controls $(\mathrm{Cn})$. All carcasses were held at a cooler temperature of $60^{\circ} \mathrm{F}$ for $1 \mathrm{~h}$ post-stimulation. Thirty-six bull and steer carcasses were then moved to a $33^{\circ} \mathrm{F}$ cooler. Thirty-five bull and steer carcasses remained in the $60^{\circ} \mathrm{F}$ cooler for an additional $12 \mathrm{~h}$ postmortem, after which time they were placed in the $33^{\circ} \mathrm{F}$ cooler.

Carcass Evaluation. Intact longissimus (ribeye) muscle tem-

${ }^{1}$ Crouse is the research leader, Meats Unit; Seideman is a research food technologist, Meats Unit, MARC; and Cross is a professor of animal science, Texas A\&M University (formerly research leader, Meats Unit, MARC). perature and $\mathrm{pH}$ of each side were measured at stimulatio and at $1,2,3,6,12,18$, and $48 \mathrm{~h}$ post-stimulation.

Carcasses were evaluated for quality and yield at $48 \mathrm{~h}$ post mortem. Lean color of the longissimus muscle at the 12th ril was scored from $1=$ light cherry red through 8 = very dar red after at least a 30-min bloom period.

Sensory Panel. A descriptive attribute panel was usec Panelists evaluated each sample according to differences i juiciness ( $1=$ extremely dry, $8=$ extremely juicy), ease $c$ fragmentation ( 1 = extremely difficult, $8=$ extremely easy). amount of connective tissue ( $1=$ abundant, $8=$ none $)$, overa tenderness $(1=$ extremely tough, $8=$ extremely tender), an flavor intensity ( 1 = extremely bland, 8 = extremely intense)

\section{Results}

Sex Effects. Bulls had a slower rate of carcass temperature decline than steers. Differences between bulls and steers in carcass temperature diminished with time in the cooler $r \epsilon$. sulting in a significant sex $x$ time interaction. The two group ; of carcasses reached equilibrium after being in the cooler fc a 48-h period, as would have been expected over this tim ? period. Evidently, heavier carcass weights and thicker longis . simus muscles of bulls resulted in a slower chill rate than the I of steers.

The longissimus muscles of bulls had higher $\mathrm{pH}$ values tha steers. Differences between bulls and steers in $\mathrm{pH}$ were mair tained during the 48-h cooler period.

Means for carcass traits are given in Table 1. Bull beef wa : darker in color and possessed more advanced lean maturit ratings than steers. Bulls were about 1 month older than steer:

Bulls had less marbling and lower quality grades than steer : (Table 1). Bulls also had heavier side weights, larger 12th-ri : longissimus muscle areas, and were trimmer than steers.

Cooler Temperature. Least-squares means and standard e . rors for high $\left(60^{\circ} \mathrm{F}\right)$ and low $\left(33^{\circ} \mathrm{F}\right)$ temperature treatments ar : given in Table 2. Lean meat (12th rib) of the $60^{\circ} \mathrm{F}$ temperatur : carcasses was slightly less mature in appearance than lea. meat from the $33^{\circ} \mathrm{F}$ temperature treatment. Although $60^{\circ} \mathrm{F} 12 \mathrm{th}$. rib longissimus lean color tended to be lighter in color than th: of $33^{\circ} \mathrm{F} 12$ th-rib lean, the difference was not statistically si? nificant. The practical importance of differences observed lean maturity are questionable.

With the exception of kidney, pelvic, and heart fat (KPH variation in the remainder of the traits observed in the cools was not associated with temperature conditions. There is $r$ : explanation apparent to the authors for reduced amounts $\mathrm{KPH}$ fat in the $33^{\circ} \mathrm{F}$ group.

Electrical Stimulation. Electrical stimulation had no effect c . carcass temperature. Electrical stimulation did, however, rest | in a more rapid $\mathrm{pH}$ decline. The more rapid $\mathrm{pH}$ decline of $\mathrm{E}$ : sides was not associated with improved tenderness. Ultimal: $\mathrm{pH}$ values for the ES and control sides were similar at $48 \mathrm{~h}$

Electrically stimulated sides were lighter in color and exhil. ited more youthful 12th-rib longissimus muscle lean maturi ! scores than control sides (Table 3). However, no difference : in quality grades were observed between sides. Heavier weigh : of electrically stimulated sides (right side) are likely due splitting errors and/or variation in KPH fat distribution. $\mathrm{C} \varepsilon$ : casses were graded after a 48-h chill; therefore, lack of ir proved quality grades due to electrical stimulation was $\mathrm{n}$ : unexpected. Previous research indicated that ES could be u i. lized to improve certain quality-indicating characteristics when carcasses were ribbed after a 24-h chill.

Sex condition $x$ ES interactions for palatability traits (exce) 
lavor) were the only statistically significant interactions. Sensory panel means for sex $x$ ES subclasses are presented in able 4. Electrical stimulation improved palatability characterstics about one-half a panelist score within the steer group. towever, no improvement in palatability characteristics was bserved in the bulls. Steers had lower $\mathrm{pH}$ and carcass temjeratures than bulls. The lower $\mathrm{pH}$ of bulls may have been issociated with decreased antemortem glycogen levels of bulls. .ower glycogen levels may have prevented violent contraction equired for muscle fiber disruption or lysosomal enzyme reease described. However, another very likely explanation for he sex $x$ ES interaction was that variation in tenderness in uulls is primarily related to variation in connective tissue and ot variation in the myofibrillar component.

Effects of cooler temperature (CT) and sex were important or sensory characteristics. The lack of a meaningful interaction vould indicate that $\mathrm{CT}$ affected bull and steer carcasses equally. Of interest, however, is whether or not high temperature con-

Table 1.-Means of carcass traits for bulls and steers

\begin{tabular}{|c|c|c|}
\hline rait & Bulls & Steers \\
\hline Jumber (sides) . . . . . . . . . . . . . & 88 & 54 \\
\hline Zolora $\ldots \ldots \ldots \ldots \ldots \ldots \ldots \ldots$ & 5.82 & 5.30 \\
\hline ean maturity ${ }^{\circ} . \ldots \ldots \ldots \ldots \ldots \ldots$ & 2.00 & 1.89 \\
\hline Aarbling ${ }^{c} \ldots \ldots \ldots \ldots \ldots \ldots \ldots \ldots$ & 6.94 & 8.91 \\
\hline JSDA quality graded $\ldots \ldots \ldots \ldots \ldots$ & 7.11 & 8.39 \\
\hline jide weight, lb $\ldots \ldots \ldots \ldots \ldots \ldots$ & 387 & 316 \\
\hline at thickness, in . . . . . . . . . . & .3 & .5 \\
\hline ongissmus area, $i^{2} \ldots \ldots \ldots \ldots$ & 13.6 & 10.8 \\
\hline (PH fat, pct. ............... & 1.98 & 2.58 \\
\hline JSDA yield grade $\ldots \ldots \ldots \ldots \ldots$ & 2.60 & 3.44 \\
\hline
\end{tabular}

aScored: $1=$ light to $8=$ very dark

bScored: $1=A-, 2=A^{\circ}, 3=A+$

'Scored: $6=$ traces,$+ 7=$ slight,$- 8=$ slight $^{\circ}, 9=$ slight + .

dScored: $7=$ Good-, $8=$ Good $^{\circ}, 9=$ Good + .

Table 2.-Means of traits for high and low cooler temperatures

\begin{tabular}{lcc}
\hline rait & High $\left(60^{\circ} \mathrm{F}\right)$ & Low $\left(33^{\circ} \mathrm{F}\right)$ \\
\hline Jumber $\ldots \ldots \ldots \ldots \ldots \ldots \ldots \ldots$ & 70 & 72 \\
Jolor. $\ldots \ldots \ldots \ldots \ldots \ldots \ldots \ldots$ & 5.51 & 5.60 \\
ean maturity $\ldots \ldots \ldots \ldots \ldots$ & 1.88 & 2.00 \\
Marbling $\ldots \ldots \ldots \ldots \ldots \ldots \ldots$ & 7.68 & 8.17 \\
\hline
\end{tabular}

ditioning $\left(60^{\circ} \mathrm{F}\right)$ improved palatability of meat obtained from bull carcasses to approximate meat obtained from steer carcasses under normal chilling conditions $\left(33^{\circ} \mathrm{F}\right)$. Means for meat from $60^{\circ} \mathrm{F}$ bulls for fragmentation ease, amount of connective tissue, and tenderness are generally within one-half a palatability score of meat from $33^{\circ} \mathrm{F}$ steers. This compared with a difference of one unit in taste panel scores for $33^{\circ} \mathrm{F}$ bulls vs $33^{\circ} \mathrm{F}$ steers.

It was concluded that high temperature carcass conditioning and ES were not adequate treatments to improve the palatability of meat obtained from bulls to equal meat obtained from steers. Sensory panel perceived connective tissue was highly associated with panel scores for tenderness, which suggests that variation in tenderness was affected primarily by connective tissue. Consequently, subsequent studies of the effects of sex on connective tissue and the relationship of connective tissue to palatability are recommended.

Table 3.-Least-squares means of traits for electrically stimulated and control sides

\begin{tabular}{|c|c|c|}
\hline Traita & Stimulated & Control \\
\hline Number .. & 71 & 71 \\
\hline Color........... & 5.33 & 5.78 \\
\hline Lean maturity ..... & 1.89 & 2.00 \\
\hline 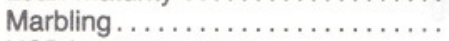 & 7.97 & 7.88 \\
\hline USDA quality grade $\ldots \ldots \ldots \ldots \ldots$ & 7.82 & 7.69 \\
\hline
\end{tabular}

aSee Table 1 for a description of traits.

Table 4.-Least-squares means of sensory panel traits for sex $x$ electrical stimulation subclasses

\begin{tabular}{|c|c|c|c|c|}
\hline \multirow[b]{2}{*}{ Trait ${ }^{\mathrm{ab}}$} & \multicolumn{2}{|c|}{ Bull } & \multicolumn{2}{|c|}{ Steer } \\
\hline & ES & Control & ES & Control \\
\hline Number ............ & 43 & 43 & 27 & 25 \\
\hline Fragmentation ease ${ }^{a} \ldots \ldots$. & 5.30 & 5.41 & 6.56 & 6.03 \\
\hline Amt. connective tissue ${ }^{b} . . .$. & 5.02 & 5.14 & 6.33 & 5.82 \\
\hline Tenderness ${ }^{c} . \ldots \ldots \ldots \ldots$ & 5.25 & 5.36 & 6.57 & 6.06 \\
\hline Flavord $\ldots \ldots \ldots$. & 5.27 & 5.51 & 5.73 & 5.46 \\
\hline
\end{tabular}

aScored: $1=$ extremely difficult to $8=$ extremely easy.

Scored: $1=$ Abundant to $8=$ none.

'Scored: $1=$ extremely tough to $8=$ extremely tender.

dScored: $1=$ extremely bland to $8=$ extremely intense. 